\title{
Adaptation of in vitro regeneration protocol for Brazilian wheat genotypes
}

\author{
Eduardo André Roesler ${ }^{1}$ \\ Ernandes Manfroi ${ }^{1}$ Andréa Morás ${ }^{2}$ \\ Dielli Aparecida Didoné ${ }^{1}$ \\ Magali Ferrari Grando ${ }^{1}$ Elene Yamazaki Lau $^{2 *}$
}

${ }^{1}$ Faculdade de Agronomia e Medicina Veterinária, Universidade de Passo Fundo (UPF), Passo Fundo, RS, Brasil.

${ }^{2}$ Embrapa Trigo, Rodovia BR 285, km 294, CP 3081, 99050-970, Passo Fundo, RS, Brasil. E-mail: elene.yamazaki-lau@embrapa.br. "Corresponding author.

\begin{abstract}
The availability of an efficient protocol for in vitro regeneration is imperative for genetic transformation. Using genotypes adapted to the target region as a transgenic platform accelerates the development of cultivars. Therefore, this study aimed to adapt an in vitro regeneration protocol for Brazilian wheat genotypes. For this purpose, the in vitro regeneration capacity of immature embryos from six Brazilian wheat genotypes using two protocols of regeneration of somatic embryos was analysed. Furthermore, combinations of 2,4-D and picloram in the callus induction medium were tested in order to improve regeneration efficiency. Genotypes with higher regeneration efficiency were BR18-Terena and PF020037, yielding 0.42 and 1.13 shoots per explant using the Hu and the Wu protocol, respectively. Adding $1 \mathrm{mgL} L^{-1}$ 2,4-D in the callus induction medium was the most favourable, producing 3.73 and 3.07 shoots per explant for PF020037 and BR18-Terena, respectively. In conclusion, a protocol for regeneration for two Brazilian wheat genotypes recommended and developed to be cultivated at the Cerrado region has been adapted.

Key words: Triticum aestivum, tissue culture, growth regulators.
\end{abstract}

Adaptação do protocolo de regeneração in vitro para genótipos de trigo brasileiros

RESUMO: A disponibilidade de um protocolo eficiente de regeneração in vitro é imperativa para a transformação genética de plantas. O uso de material genético adaptado à região alvo como plataforma de transgenia permite acelerar o desenvolvimento de uma cultivar. Portanto, o objetivo deste estudo foi adaptar um protocolo de regeneração in vitro para genótipos brasileiros de trigo. Para esta finalidade, a capacidade de regeneração in vitro de embriões imaturos de seis genótipos brasileiros de trigo, utilizando dois protocolos de regeneração de embriões somáticos, foi analisada. Além disso, combinações de 2,4-D e picloram no meio de indução de calos foram analisadas buscando aumentar a eficiência de regeneração. Os genótipos com maior eficiência de regeneração foram BR18-Terena e PF020037, produzindo 0,42 e 1,13 brotações por explante usando os protocolos Hu e Wu, respectivamente. A adição de $1 m g L^{-1}$ de 2,4-D no meio de indução de calos foi o mais favorável, produzindo 3,73 e 3,07 brotações por explante para PF020037 e BR18-Terena, respectivamente. Concluindo, foi adaptado um protocolo de regeneração para dois genótipos brasileiros recomendados e desenvolvidos para o cultivo no Cerrado.

Palavras-chave: Triticum aestivum, cultura de tecidos, reguladores de crescimento.

\section{INTRODUCTION}

In Brazil, about $90 \%$ of the wheat is grown in the southern region. But domestic production can supply only about half of domestic demand. Therefore, there is a great appeal for a greater occupation of the Brazilian Cerrado, which has 2.7 million hectares of estimated area favourable to the culture (PASINATO, 2017). Though, it still has several impairments to display its full productivity potential, such as blast disease, hydric deficit, and heat, which hamper growing in the Brazilian Cerrado. Some of these are difficult traits to be obtained by traditional breeding, but genetic modification technology can assist to reach this aim. However, it is not trivial to establish a wheat genetic transformation protocol, notably using Agrobacterium tumefaciens; because, in addition to the multitude of factors affecting this technique (ZIEMIENOWICZ, 2014), the response window is considered narrower compared to other cereals (HIEI et al., 2014).

In vitro regeneration capacity is one of the factors that may be prohibitive to get transgenic plants. Such studies in wheat have been made since the 70s (SHIMADA, 1978) until currently (ZHANG et al., 2015b; MAHMOOD \& RAZZAQ, 2017), confirming that regeneration is a key step for transgenesis. Regeneration per se has several key factors, such as plant growth regulator types and concentration in the culture medium (MAHMOOD \& RAZZAQ, 2017) which may vary according to plant genotype and 
the availability of genotypes responsive to in vitro culture and to the genetic transformation process. Bobwhite and Fielder are model cultivars for in vitro regeneration and genetic transformation purposes. However, they are not agronomically superior, requiring backcrosses to transfer the transgene to elite genotypes, demanding more time to generate a commercial cultivar. Using elite genotypes is quite interesting because it can be readily incorporated into breeding programs and has been the subject of studies (GRUSZKA VENDRUSCOLO et al., 2008; ZHANG et al., 2015a). Furthermore, by being adapted to the local environment, local genotypes may generate physiologically suitable explants for transformation.

The most commonly used explant for wheat in vitro culture is the immature embryo, which regenerates via somatic embryogenesis (SE) (SINGH \& PRASAD, 2016). SE is 'the process of differentiation of cells into a plant bypassing the fusion of gametes', according to SMERTENKO \& BOZHKOV (2014). Picloram and 2,4-D are herbicides with growth regulator function most often used for SE in wheat (WU et al., 2009; RICHARDSON et al., 2014; SPARKS et al., 2014). Somatic embryo induction is related to stress application in cells, including that caused by 2,4-D (FEHÉR, 2015).

Therefore, this study aimed to adapt an in vitro regeneration protocol for Brazilian wheat genotypes, using two protocols of regeneration of somatic embryos, six Brazilian genotypes, moreover improving the culture media for genotypes with best regeneration efficiency using combinations of growth regulators picloram and 2,4-D.

\section{MATERIALS AND METHODS}

Donor plants of immature embryos (explants) were: BR18-Terena, MGS1 Aliança, MGS3 Brilhante, PF020037, PF020062 (all of the above are for rainfed cultivation), and BRS 264 (irrigated cultivation) and Bobwhite SH 9826 (responsive control for in vitro regeneration and genetic transformation).

Plants were grown in $8 \mathrm{~L}$ pots, with topdressing at tillering with NPK 5-25-25 and urea (1g/ pot) in a mixture of soil and vermiculite (1:1) in genotype trials; and $0.8 \mathrm{~g}$ urea/pot, 7.5g OsmocotePlus 15-9-12/ pot and $0.75 \mathrm{~g}$ PG-mix 14-16-18 + micronutrients/pot in a mixture of soil : vermiculite : substrate (Mecplant Florestal 1C) (1:1:1) in assays for culture media improvement. Plants were kept in growth chambers with $20^{\circ} \mathrm{C}$ day, $14^{\circ} \mathrm{C}$ night, $16 \mathrm{~h}$ photoperiod, approximately $110 \mu$ molesm $^{-2} \mathrm{~s}^{-1}$. Spikes were collected 10 to 16 days after anthesis. Immature embryos were 1.0 to $1.5 \mathrm{~mm}$ in length with a creamy translucent appearance. Fungicidal and insecticidal were applied as needed.

Seeds were sterilised in $70 \%(\mathrm{v} / \mathrm{v})$ ethanol for $1 \mathrm{~min}$, and $50 \%(\mathrm{v} / \mathrm{v})$ commercial bleach solution added with Tween 20 to $0.1 \%$ (v/v) for $10 \mathrm{~min}$, followed by five rinses with sterile water. Explants were removed aseptically from the seeds and the embryonic axis was excised and they were placed on the culture medium with scutellum facing up. Explants were maintained in the culture room at $25 \pm 2{ }^{\circ} \mathrm{C}$ in the dark or light according to the protocols described below.

In order to identify the most responsive genotypes, their immature embryos were submitted to culture media based on that of $\mathrm{Hu}$ et al. (2003) and of Wu et al. (2009), both with modifications (Table 1), termed the $\mathrm{Hu}$ and the $\mathrm{Wu}$ protocols, respectively. These protocols are for genetic transformation and have no description of the regeneration efficiency, so the results of the present research were compared to other. In the $\mathrm{Hu}$ protocol, explants were placed on CM4C medium (pre culture, callus induction medium) in the dark for four days. After that, explants were placed in $60 \mathrm{~mm}$ diameter disposable Petri dishes (JProlab) containing filter paper moistened with water for two to three days in the dark and then transferred to resting medium (callus induction medium) and kept in the dark for additional two weeks. Calli were transferred to the medium MMS0.2C $\left(1^{\text {st }}\right.$ regeneration medium) and placed in the light for two weeks. After this time they were transferred to Magenta boxes containing about $50 \mathrm{ml}$ of MMS0C ( $2^{\text {nd }}$ regeneration medium) for three weeks in the light. The calli were transferred to new MMS0C for three weeks in light and evaluated. In the $\mathrm{Wu}$ protocol, the explants were placed on inoculation/ co-cultivation medium, kept for three days and then transferred to the callus induction medium for three weeks. Explants were maintained in the dark until this step. Then, calli were transferred to regeneration media, under light from this step on, and maintained for three weeks. Calli were transferred to Magenta boxes containing about $50 \mathrm{ml}$ of selection medium, maintained for three weeks, transferred to new selection medium, kept for another three weeks and evaluated. So, in this assay the in vitro response of seven wheat genotypes to two regeneration protocols were evaluated.

In the second assay, the culture media based on $\mathrm{Wu}$ protocol were used aiming regeneration efficiency improvement of the explants from PF020037 and BR18-Terena. In addition to previous modifications (Table 1), the induction medium was supplemented with $5 \mu \mathrm{M} \mathrm{CuSO} \mathrm{Cu}_{4} .5 \mathrm{H}_{2}$ and $1.03 \mathrm{gL}^{-1}$ $\mathrm{CaCl}_{2} \cdot 2 \mathrm{H}_{2} \mathrm{O}$. In this medium, the combination of 0,1 , 
Table 1 - Culture medium used for induction and regeneration of wheat embryo genic calli.

Culture medium Protocol according to $\mathrm{Hu}$ et al. (2003)

CM4C: MS macro and micronutrients, MS FeNa 2 .EDTA, MS vitamins, $100 \mathrm{mgL}^{-1}$ inositol, $100 \mathrm{mLL}^{-1}$ ascorbic acid, $40 \mathrm{gL}^{-1} \mathrm{maltose}$

$0.5 \mathrm{mgL}^{-1}$ 2,4-D (AcrosOrganics), $2.2 \mathrm{mgL}^{-1}$ picloram (Sigma), $7 \mathrm{gL}^{-1}$ agar (Sigma), pH 5.8

Resting: same components of CM4C, except using $2 \mathrm{mgL}^{-1} 2,4-\mathrm{D}$

MMS0.2C: same components of CM4C, except using $0.2 \mathrm{mgL}^{-1} 2,4-\mathrm{D}$ and absence of picloram

MMS0C: same components of CM4C, except using $0.1 \mu \mathrm{M}$ L-tryptophan, $0.1 \mu \mathrm{M}$ L-tyrosine, $0.1 \mu \mathrm{M}$ L-phenylalanine, and absence of 2,4$\mathrm{D}$ and picloram

Culture medium according to Wu et al. (2009)-

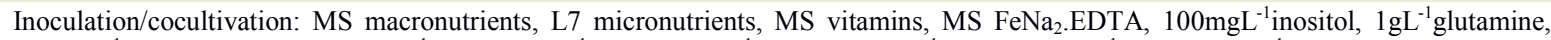
$100 \mathrm{mgL}^{-1}$ caseinhydrolysate, $1.95 \mathrm{gL}^{-1} \mathrm{MES}, 2 \mathrm{mgL}^{-1} 2,4-\mathrm{D}, 2 \mathrm{mgL}^{-1}$ picloram, $10 \mathrm{gL}^{-1}$ glucose, $40 \mathrm{gL}^{-1} \mathrm{maltose}, 2 \mathrm{gL}^{-1} \mathrm{phytagel}, \mathrm{pH}^{2} .7$

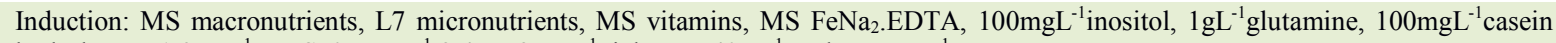
hydrolysate, $1.95 \mathrm{gL}^{-1} \mathrm{MES}, 0.5 \mathrm{mgL}^{-1} 2,4-\mathrm{D}, 2 \mathrm{mgL}^{-1}$ picloram, $40 \mathrm{gL}^{-1}$ maltose, $7 \mathrm{gL}^{-1}$ agar, $\mathrm{pH} 5.7$

Regeneration: L7 macro and micronutrients, MS FeNa 2 EDTA, L vitamins/inositol (200mgL $\mathrm{mositol}^{-1} 10 \mathrm{mgL}^{-1}$ thiamine-HCl, $1 \mathrm{mgL}^{-1}$ pyridoxine-HCl, $1 \mathrm{mgL}^{-1}$ ascorbic acid, $1 \mathrm{mgL}^{-1}$ calcium pantothenate, $1 \mathrm{mgL}^{-1}$ ascorbic acid), $100 \mathrm{mgL}^{-1}$ inositol, $30 \mathrm{gL}^{-1} \mathrm{maltose} 0.1 \mathrm{mgL}^{-1}$ 2,4-D, $5 \mathrm{mgL}^{-1}$ zeatin (Sigma), $7 \mathrm{gL}^{-1}$ agar, $\mathrm{pH} 5.7$

Selection: same components of Regeneration, except absence of 2,4-D and zeatin.

and $2 \mathrm{mgL}^{-1}$ picloram (P0, P1, and P2) with 0,1 and $2 \mathrm{mgL}^{-1} 2,4-\mathrm{D}$ (D0, D1 and D2) were tested. At the final step of the protocol, calli were transferred to selection medium, maintained for three weeks and evaluated.

In all steps, except when mentioned and those using the MMSOC and selection media, $90 \mathrm{~mm}$ diameter disposable Petri dishes (JProlab) containing about $30 \mathrm{ml}$ of each culture medium were used.

The parameters evaluated were the proportion of explants with regenerated shoots (ER) and the number of shoots per total number of callus (SC). All shoots were considered as a unit, individualised or not. The experiment to identify genotypes was repeated at least twice and for testing the callus induction medium once.

All the experiments were carried out in completely randomised design with the treatments arranged in the factorial design. The experimental unit was a Petri dish with fifteen to seventeen explants. For protocols and genotypes assay, each treatment had four replicates. For callus induction medium assay, ten replicates were used in each treatment.

For statistical analysis, the data were transformed to squared root and then subjected to two-way analysis of variance (ANOVA) for $F$-test. When $F$ was significant $(\mathrm{P}<0.05)$ the means were compared by the Tukey post-hoc test. The data were analysed using the GLIMMIX procedure of the SAS ${ }^{\circledR}$ software.

\section{RESULTS AND DISCUSSION}

In this research, it was sought to identify Brazilian wheat genotypes responsive to SE testing two regeneration protocols and to improve the regeneration efficiency of the most responsive ones modifying the induction medium. These genotypes are an interesting platform considering their future use in solving wheat problems for cultivation in the Brazilian Cerrado region, such as wheat blast resistance and drought tolerance, through genetic engineering.

BR18-Terena and PF020037 were the genotypes with higher ER and SC (Table 2). Bobwhite and PF020037 were the most responsive to the $\mathrm{Wu}$ protocol (38.2\% and $42.7 \%$ ER, respectively), while BR18-Terena was the highlight $(47.6 \%$ ER) in Hu. Except for BR18-Terena, ER of all other genotypes was not affected by the protocol type. There was no effect of the protocol type related to $\mathrm{SC}$ variable and $\mathrm{Wu}$ produced higher $\mathrm{SC}$ than $\mathrm{Hu}$. Considering the two variables, the same genotypes stood out. Other genotype response did not differ significantly in both protocols and regenerated up to $11.4 \%$ and produced up to $0.24 \mathrm{SC}$.

Most of the explants produced callus and only these were considered for analysis. Calli formed in both protocols were generally milky, friable, and when present, the leaf primordia become chlorophyllous two to five days after light exposure. Calli formed in $\mathrm{Wu}$ were visually larger than those produced from $\mathrm{Hu}$. After incubation on regeneration or resting medium, embryogenic calli with regeneration presented leaf structures, while the non-embryogenic or non-regenerated remained with cream or green regions (Figures 1A and 1B). Not all calli with leaf structures produced shoots.

Using similar culture media from the $\mathrm{Wu}$ protocol, the cultivar Florida presented $74.6 \%$ ER (WU et al., 2003), higher than any genotype tested in

Ciência Rural, v.48, n.11, 2018. 
Table 2 - In vitro regeneration of Brazilian wheat genotypes in two regeneration protocols.

\begin{tabular}{|c|c|c|c|c|}
\hline \multirow[b]{2}{*}{ Wheat genotype } & \multicolumn{2}{|c|}{ Explants with shoots regeneration (\%) } & \multirow{2}{*}{\multicolumn{2}{|c|}{ Number of shoots per explant }} \\
\hline & $\mathrm{Hu}^{(1)}$ & $\mathrm{Wu}^{(2)}$ & & \\
\hline Bobwhite SH9826 & $27.1 \mathrm{abA}$ & $42.0 \mathrm{aA}$ & \multicolumn{2}{|c|}{$1.00 \mathrm{a}$} \\
\hline BR18-Terena & $47.6 \mathrm{aA}$ & $22.5 \mathrm{abB}$ & \multicolumn{2}{|c|}{$0.42 \mathrm{ab}$} \\
\hline BRS 264 & $8.2 \mathrm{bcA}$ & $11.4 \mathrm{bcA}$ & \multicolumn{2}{|c|}{$0.24 b c$} \\
\hline MGS1 Aliança & $0.9 \mathrm{bcA}$ & $8.8 \mathrm{bcA}$ & \multicolumn{2}{|c|}{$0.10 \mathrm{bc}$} \\
\hline MGS3 Brilhante & $8.8 \mathrm{cA}$ & $2.5 \mathrm{cA}$ & \multicolumn{2}{|c|}{$0.03 \mathrm{c}$} \\
\hline PF020037 & $24.0 \mathrm{abA}$ & $42.7 \mathrm{aA}$ & \multicolumn{2}{|c|}{$1.13 \mathrm{a}$} \\
\hline \multirow[t]{3}{*}{ PF020062 } & $9.4 \mathrm{bcA}$ & $8.1 \mathrm{bcA}$ & \multicolumn{2}{|c|}{$0.16 b c$} \\
\hline & & & $\mathrm{Wu}$ & $\mathrm{Hu}$ \\
\hline & & & $0.58 \mathrm{~A}$ & $0.32 \mathrm{~B}$ \\
\hline
\end{tabular}

Regeneration protocol according to ${ }^{(1)} \mathrm{Hu}$ et al. (2003) and to ${ }^{(2)} \mathrm{Wu}$ et al. (2009). Means followed by same uppercase letter in the row and lowercase letter in the column do not statistically differ by Tukey post-hoc test $(\mathrm{P}<0.05)$.

the present research. The PF020037, which presented one of best results, produced only $42.7 \%$ ER and $1.63 \mathrm{SC}$ on the $\mathrm{Wu}$ protocol. Bobwhite ER was $75 \%$ in Mexico (PELLEGRINESCHI et al., 2002) and 99\% and 15.00 SC in Turkey (HALILOGLU et al. 2013), suggesting that at least for this material, the conditions of the present research were not optimal. HALILOGLU \& BAEZINGER (2005) obtained 1.80 $\mathrm{SC}$ for Bobwhite, with the same in vitro conditions of HALILOGLU et al. (2013). On those three researches with Bobwhite, donor plants were grown in greenhouse, field and growth chamber. A possible reason for different results may be the physiological condition of donor plants, so improvements in this sense may be pursued.

Among several differences of the two protocols perhaps most important is the growth regulator concentration in the corresponding media. Embryogenic callus induction and regeneration abilities are dependent on the plant genotype (TANG et al., 2006; RASHID et al., 2009), requiring, among other things, adjustments in type and concentration of growth regulators. Therefore, we tested growth regulator combinations aiming to improve the regeneration efficiency of PF020037 and BR18Terena. The protocol $\mathrm{Wu}$ was chosen for these experiments because it was promising for two of the tested genotypes; callus appearance was visually better and it had best local adaptation.

All sprouts of the P0-D0 treatment were from seed germination (Figure 1C-E) and not from embryogenesis, thus it was considered as no shoots. By ANOVA, there was interaction between picloram and 2,4-D effects for both variables ER and SC in the two genotypes assayed. The most prominent treatment was P0-D1 (Figure 1F-H, Figure 2A-C, Table 3), with 3.73 SC and 61.2\% ER for PF020037 and $3.07 \mathrm{SC}$ and $60.8 \%$ ER for BR18-Terena. Considering only the explants with shoots, these genotypes produced 6.09 and 5.05 SC, respectively. Using 2,4-D alone was better for BR18-Terena, so the combination of picloram and 2,4-D was not favourable for this genotype (Table 3 and Figure 1). Overall, PF020037 presented numerically higher means than did BR18-Terena, indicating that it may be more responsive in vitro or more adapted to these conditions. The addition of 1 or $2 \mathrm{mgL}^{-1}$ of picloram or 2,4-D was beneficial to PF020037 regeneration but dosage did not matter. The only statistically significant differences among treatments containing both growth regulators were P1-D1 (59.4\% ER) and P2-D1 (27.1\% ER). In PF020037 P1-D0, shoots were formed at the end of incubation on induction medium, and the explants were transferred to selection medium ten days earlier than the other treatments (Figure 2D-F). Unlike the others, shoots were not individualised (Figure $2 \mathrm{~F}$ ), being probably regenerated by organogenesis. The PF020037 in P2D0 also formed similar shoots, but fewer and with lower growth rate. Thus, adding $1 \mathrm{mgL}^{-1}$ picloram to callus induction medium can speed up the regeneration process of PF020037.

TheBR18-Terena in P2-D2, at concentrations similar to those of the resting medium $(\mathrm{Hu})$, showed only $8.9 \%$ ER and $0.22 \mathrm{SC}$ which is less than that obtained in the initial experiment $(47.6 \%$ ER and 0.42 SC, Table 2). The opposite occurred with PF020037, ranging from $24.0 \% \mathrm{ER}$ and $1.13 \mathrm{SC}$ to $48.5 \% \mathrm{ER}$ and $1.47 \mathrm{SC}$, the former to the second experiment. Possibly the small difference in the picloram concentration has 


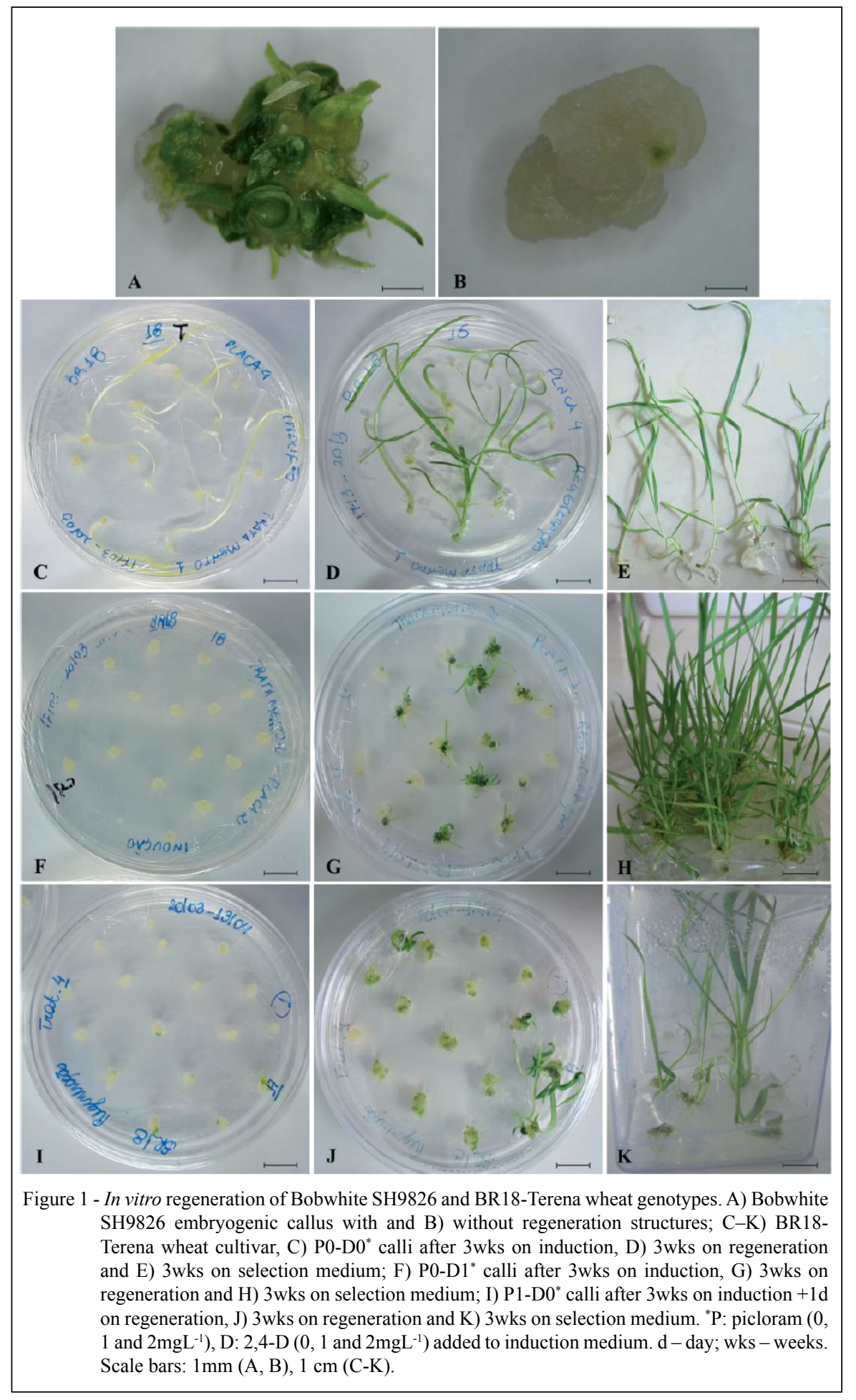

affected the result or components of the resting medium are favourable to BR18-Terena and unfavourable to PF020037. Compared to the induction medium (Wu), in which PF020037showed $42.7 \%$ ER and 1.13 SC and BR18-Terena $22.5 \%$ ER and 0.42 SC, P2-D1 (containing similar concentration) presented similar results with $27.1 \%$ and $21.6 \% \mathrm{ER}$ and 1.61 and $0.77 \mathrm{SC}$, respectively (Table 2 and Table 3 ), for these genotypes. 


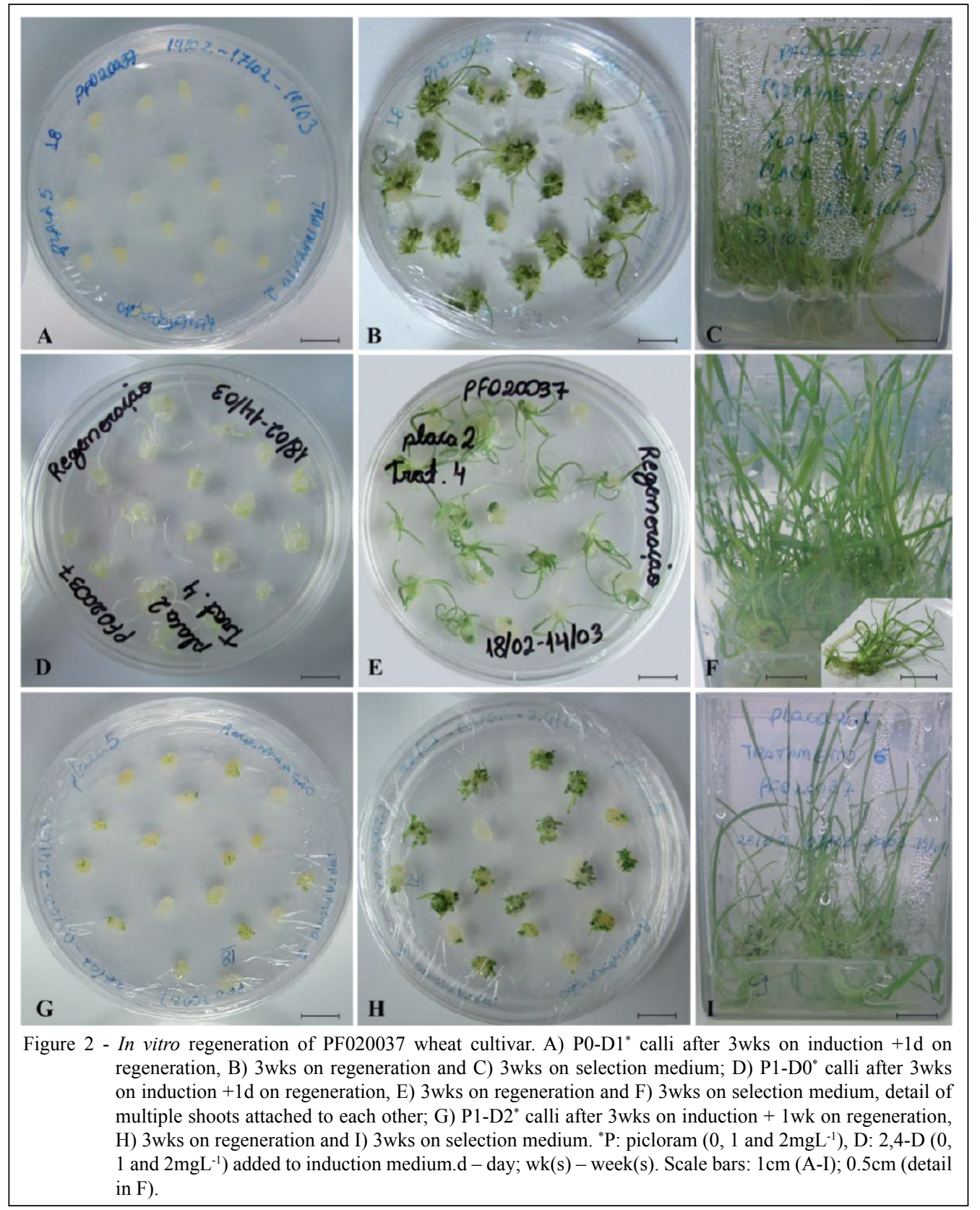

There was a significant improvement in the regeneration efficiency, from $47.6 \%$ and $42.7 \%$ ER and 0.42 and 1.13 SC for BR18-Terena and PF020037, respectively, to $60.8 \%$ and $61.2 \%$ ER and 3.07 and $3.73 \mathrm{SC}$ (Table 2 and Table 3 ), even considering that the evaluation was advanced three weeks compared to the previous experiment. The longer the time in culture medium there was a tendency to produce more shoots/tillers. The difference between substrates in donor plants growing, $\mathrm{CuSO}_{4} \cdot 5 \mathrm{H}_{2} \mathrm{O}$ and $\mathrm{CaCl}_{2} \cdot 2 \mathrm{H}_{2} \mathrm{O}$ addition in the medium, may have contributed to the improvement as well.

In another study with Brazilian genotypes using P2.2-D1 in induction medium, the best result was $99.5 \%$ embryogenic callus formation and 1.10 shoots per embryogenic callus (GRUSZKA VENDRUSCOLO et al., 2008). In a study of Chinese cultivars, the best ER was close to $65 \%$ (TANG et al., 2006). European cultivars Florida and Brigadier produced embryogenic calli in induction medium 
Table 3 - In vitro regeneration of BR18-Terena and PF020037 wheat genotypes upon different concentrations of picloram and 2,4-D in callus induction medium.

\begin{tabular}{|c|c|c|c|c|c|c|c|}
\hline & & \multirow{2}{*}{\multicolumn{3}{|c|}{ - }} & \multirow{2}{*}{\multicolumn{3}{|c|}{ 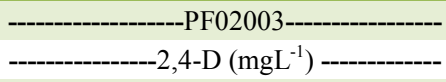 }} \\
\hline & & & & & & & \\
\hline & & 0 & 1 & 2 & 0 & 1 & 2 \\
\hline \multirow{3}{*}{ Picloram $\left(\mathrm{mgL}^{-1}\right)$} & 0 & $0.0 \mathrm{cB}$ & $60.8 \mathrm{aA}$ & $40.8 \mathrm{aA}$ & $0.0 \mathrm{bB}$ & $61.2 \mathrm{aA}$ & $55.1 \mathrm{aA}$ \\
\hline & 1 & $7.3 \mathrm{bB}$ & $26.2 \mathrm{bA}$ & $12.3 \mathrm{bA}$ & $54.6 \mathrm{aA}$ & $59.4 \mathrm{aA}$ & $44.5 \mathrm{aA}$ \\
\hline & 2 & $20.1 \mathrm{aA}$ & $21.6 \mathrm{bA}$ & $8.9 \mathrm{bA}$ & $43.4 \mathrm{aAB}$ & $27.1 \mathrm{bB}$ & $48.5 \mathrm{aA}$ \\
\hline \multicolumn{5}{|c|}{-Bor } & \multicolumn{3}{|c|}{ - } \\
\hline & & \multicolumn{3}{|c|}{ - $2,4-\mathrm{D}\left(\mathrm{mgL}^{-1}\right)$} & \multicolumn{3}{|c|}{ - $2,4-\mathrm{D}\left(\mathrm{mgL}^{-1}\right)$} \\
\hline & & 0 & 1 & 2 & 0 & 1 & 2 \\
\hline \multirow{3}{*}{ Picloram $\left(\mathrm{mgL}^{-1}\right)$} & 0 & $0.00 \mathrm{bC}$ & $3.07 \mathrm{aA}$ & $1.63 \mathrm{aB}$ & $0.00 \mathrm{bB}$ & $3.73 \mathrm{aA}$ & $2.68 \mathrm{aA}$ \\
\hline & 1 & $0.20 \mathrm{bB}$ & $1.09 \mathrm{bA}$ & $0.26 \mathrm{bAB}$ & $3.12 \mathrm{aA}$ & $1.95 \mathrm{abA}$ & $1.53 \mathrm{aA}$ \\
\hline & 2 & $0.57 \mathrm{aA}$ & $0.77 \mathrm{bA}$ & $0.22 \mathrm{bA}$ & $2.54 \mathrm{aA}$ & $1.61 \mathrm{bA}$ & $1.47 \mathrm{aA}$ \\
\hline
\end{tabular}

The experiment was evaluated three weeks after calli were transferred to the selection medium. Means followed by same uppercase letter (inside genotype) in the row and lowercase letter in the column do not statistically differ by Tukey post-hoc test $(\mathrm{P}<0.05)$.

containing $2 \mathrm{mgL}^{-1}$ picloram which regenerated $96 \%$ and $92 \%$, respectively (BARRO et al., 1999). MITIĆ et al. (2006) studied the regeneration capacity of 96 genotypes from several places around the world, and concluded that the genotype is the most important factor for regeneration potential determination. The amount of SC ranged from 1.10 to 8.90 (considering only calli with shoots). One of the best results of in the present research was $3.73 \mathrm{SC}$ or 6.09 shoots per embryogenic callus and almost $100 \%$ of explants produced callus. The comparison to other studies is complicated because the evaluation criteria differ and are not always clear. Percentage of calli with regeneration does not mean a lot of cells in regenerated shoots that can generate new plants, as they can produce few or multiple shoots.

\section{CONCLUSION}

A protocol for regeneration using immature embryos of two Brazilian wheat genotypes recommended and developed to be cultivated at the Cerrado region, BR18-Terena and PF020037, respectively, has been adapted. Considering callus induction, the addition of $1 \mathrm{mgL}^{-1} 2,4-\mathrm{D}$ into induction medium proposed by WU et al. (2009) is the most favourable for shoot production in both genotypes.

\section{ACKNOWLEDGEMENTS}

This study was funded by Empresa Brasileira de Pesquisa Agropecuária (EMBRAPA), Coordenação de Aperfeiçoamento de Pessoal de Nível Superior (CAPES) and
Conselho Nacional de Desenvolvimento Científico e Tecnológico $(\mathrm{CNPq})$. We are grateful to Márcio Nicolau for support with statistical analysis; and Fátima M. de Marchi for the artwork.

\section{DECLARATION OF CONFLICTING INTERESTS}

The authors declared no potential conflicts of interest with respect to the research, authorship, and/or publication of this article.

\section{AUTHORS' CONTRIBUTIONS}

The authors contributed equally to the manuscript.

\section{REFERENCES}

BARRO, F. et al. Medium optimization for efficient somatic embryogenesis and plant regeneration from immature inflorescences and immature scutella of elite cultivars of wheat, barley and tritordeum. Euphytica, v.108, p.161-167,1999. Available from: $<$ https://link.springer.com/article/10.1023/A:1003676830857>. Accessed: Oct. 30, 2017. doi: 10.1023/a:1003676830857.

GRUSZKA VENDRUSCOLO, E.C. et al. Callus induction and plant regeneration by Brazilian new elite wheat genotypes. Crop Breeding and Applied Biotechnology, v.8, p.195-201, 2008. Available from: <http://www.sbmp.org.br/cbab/siscbab/uploads/c8129493-b9e506bf.pdf $>$. Accessed: Oct. 30, 2017. doi: 10.12702/1984-7033. v08n03a04.

HALILOGLU, K. et al. Response of current winter wheat cultivars grown in turkey to immature embryo culture. Atatürk Üniversitesi ZiraatFakültesiDergisi, v.44, p.21-25, 2013. Available from: <http:// dergipark.gov.tr/download/article-file/35527>. Accessed: Oct. 30, 2017.

HALILOGLU, K.; BAENZIGER, P.S. Screening wheat genotypes for high callus induction and regeneration capability from 
immature embryo cultures. Journal of Plant Biochemistry and Biotechnology, v.14, p.155-160, 2005. Available from: <https:// link.springer.com/article/10.1007/BF03263244>. Accessed: Oct. 30, 2017. doi: 10.1007/BF03263244.

HIEI, Y.et al. Progress of cereal transformation technology mediated by Agrobacterium tumefaciens. Frontiers in Plant Science, v.5, p.628, 2014. Available from: <https://www.ncbi.nlm. nih.gov/pmc/articles/PMC4224067/>. Accessed: Oct. 30, 2017. doi: $10.3389 /$ fpls. 2014.00628 .

HU, T. et al Agrobacterium-mediated large-scale transformation of wheat (Triticum aestivum L.) using glyphosate selection. Plant Cell Reports, v.21, p.1010-1019, 2003. Available from: <https:// link.springer.com/article/10.1007/s00299-003-0617-6>. Accessed: Oct. 30, 2017. doi: 10.1007/s00299-003-0617-6.

MAHMOOD, I.; RAZZAQ, A. Responses of explant type of wheat (Triticum aestivumL.) genotypes to different tissue culture media. Journal of the National Science Foundation of Sri Lanka, p.45, p.265-271, 2017. Available from: <https://jnsfsl.sljol.info/articles/ abstract/10.4038/jnsfsr.v45i3.8191/>. Accessed: Oct. 30, 2017. doi: $10.4038 /$ jnsfsr.v45i3.8191.

MITIĆ, N. et al. Variability of in vitro culture response in wheat genotypes, genotype and environmental effects. Genetika, v.38, p.183-192, 2006. Available from: <http://www.doiserbia.nb.rs/ img/doi/0534-0012/2006/0534-00120603183M.pdf>. Accessed: Oct. 30, 2017. doi: 10.2298/gensr0603183m.

PASINATO, A. Potencialidades e limitações para a expansão do cultivo de trigo sequeiro no bioma cerrado do Brasil Central. 2017. 141f. Dissertação (Área de concentração Produção Vegetal) - Curso de Pós-graduação em Fitotecnia, Universidade Federal do Rio Grande do Sul.

PELLEGRINESCHI, A. et al. Identification of highly transformable wheat genotypes for mass production of fertile transgenic plants. Genome, v.45, p.421-430, 2002. Available from: <http://oar. icrisat.org/5725/1/Genome_45_\%20421\%E2\%80\%93430_2002. pdf>. Accessed: Nov. 08, 2017. doi: 10.1139/g01-154.

RASHID, U. et al. Establishment of an efficient callus induction and plant regeneration system in Pakistani wheat (Triticum aestivum) cultivars. Electronic Journal of Biotechnology, v.12, p.4-5, 2009. Available from: <http://www.ejbiotechnology.info/ index.php/ejbiotechnology/article/view/v12n3-1/72>. Accessed: Oct. 30, 2017. doi: 10.2225/vol12-issue3-fulltext-1.

RICHARDSON, T. et al. Efficient Agrobacterium transformation of elite wheat germplasm without selection. Plant Cell Tissue and Organ Culture, v.119, p.647-659, 2014. Available from: <https:// link.springer.com/article/10.1007/s11240-014-0564-7>. Accessed: Oct. 30, 2017. doi: 10.1007/s11240-014-0564-7.

SHIMADA, T. Plant regeneration from the callus induced from wheat embryo. Japanese Journal of Genetics, v.53, p.371-
374, 1978. Available from: <https://www.jstage.jst.go.jp/article/ ggs 1921/53/5/53 5 371/ article >. Accessed: Oct. 30, 2017. doi: 10.1266/jjg.53.371.

SINGH, R.K.; PRASAD, M. Advances in Agrobacterium tumefaciens-mediated genetic transformation of graminaceous crops. Protoplasma, v.253, p.691-707, 2016. Available from: $<$ https://link. springer.com/article/10.1007\%2Fs00709-015-0905-3>. Accessed: Mar. 30, 2018. doi: 10.1007/s00709-015-0905-3.

SMERTENKO, A.; BOZHKOV, P.V. Somatic embrogenesis: life and death processes during apical-basal patterning. Journal of Experimental Botany, v.65, p.1343-1360, 2014. Available from: <https://academic.oup.com/jxb/article/65/5/1343/451868>. Accessed: Mar. 30, 2018. doi: 10.1093/jxb/eru005.

SPARKS, C.A.et al. Genetic Transformation of wheat via Agrobacterium-mediated DNA delivery. In: Henry JR, Furtado A (eds) Cereal Genomics: Methods and Protocols. Humana Press, Totowa, 2014. p.235-250. Available from: <https://link.springer. com/protocol/10.1007\%2F978-1-62703-715-0_19>. Accessed: Oct. 30, 2017. doi: 10.1007/978-1-62703-715-0 19.

TANG, Z-X et al. The selection of transgenic recipients from new elite wheat cultivars and study on its plant regeneration system. Agricultural Sciences in China, v.5, p.417-424, 2006. Available from: <http://www.sciencedirect.com/science/article/ pii/S1671292706600709>. Accessed: Oct. 30, 2017. doi: 10.1016/ S1671-2927(06)60070-9.

WU, H. et al. Agrobacterium-mediated transformation of bread and durum wheat using freshly isolated immature embryos. In: Jones DH and Shewry RP (eds) Transgenic Wheat, Barley and Oats: Production and Characterization Protocols. Humana Press, Totowa, 2009, p. 93-103. Available from: <https://link.springer. com/protocol/10.1007\%2F978-1-59745-379-0_5>. Accessed: Oct. 30, 2017. doi: 10.1007/978-1-59745-379-0_5.

ZHANG, K. Biolistic genetic transformation of a wide range of chinese elite wheat (Triticum aestivum L.) varieties. Journal of Genetics and Genomics, v.42, p.39-42, 2015a. Available from: <http:// www.sciencedirect.com/science/article/pii/S1673852714002021>. Accessed: Oct. 30, 2017. doi: 10.1016/j.jgg.2014.11.005.

ZHANG, W. et al. Effects of inter-culture, arabinogalactan proteins, and hydrogen peroxide on the plant regeneration of wheat immature embryos. Journal of Integrative Agriculture, v.14, p.11-19, 2015b. Available from: < http://www.sciencedirect. com/science/article/pii/S2095311914607644>. Accessed: Oct. 30, 2017. doi: 10.1016/S2095-3119(14)60764-4.

ZIEMIENOWICZ, A. Agrobacterium-mediated plant transformation: factors, applications and recent advances. Biocatalysis and Agricultural Biotechnology, v.3, p.95-102, 2014. Available from: <http://www.sciencedirect.com/science/ article/pii/S1878818113001175>. Accessed: Oct. 30, 2017. doi: 10.1016/j.bcab.2013.10.004. 